(from the Association, 52 Bloomsbury Street, London, W.C.1. 1s.). The list is largely based on two published bibliographies, "Die deutsche Presse, 1946" and "A Check-list of Current Serials in the United States Zone of Germany". Orders for such periodicals for not less than six months subscription will be accepted on behalf of H.M. Stationery Office by the Secretary, Enemy War-time Publications Requirements Committee, Control Commission for Germany and Austria, Norfolk House, St. James's Square, London, S.W.I (see also Nature, March 15, p. 366).

\section{Spectrographic Terminology}

The Spectrographic Discussion Group at Glasgow has produced a pamphlet (University Press, Aberdeen, 1946) entitled "Suggested Definitions of Terms used in Spectrographic Analysis". This recommends a set of symbols for various spectrographic constants and suggests definitions of a large number of terms used in this type of work. The chairman of the group, Mr. S. D. Steele (c/o Messrs. Babcock and Wilcox, Renfrew, Scotland), offers to send a free copy of the pamphlet to interested persons and will welcome criticism and suggestions. The proposed symbols do not, in general, appear to conform to the principles laid down by the Joint Report of the Chemical, Faraday and Physical Societies (1937).

\section{Fourth International Congress for Microbiology}

THE International Association of Microbiologists is organising the Fourth International Congress for Microbiology, to be held at Copenhagen during July 20-26, 1947. General meetings will be addressed by Dr. F. C. Bawden (Rothamsted Experimental Station) on viruses, Prof. S. A. Waksman (New Jersey State Agricultural Experiment Station) on antibiotics and life, Prof. C. H. Werkman (Iowa State College) on the assimilation of carbon dioxide, and Prof. Ø. Winge (University of Copenhagen) on yeast in modern genetics. The nine sections of the Congress will be devoted respectively to general microbiology, medical and veterinary bacteriology, viruses and virus diseases, serology and immunology, variation and mutation in micro-organisms, plant pathology and mycology, soil and water microbiology, dairy and food microbiology, and industrial microbiology. The president of the Congress is Dr. Th. Madsen; and the honorary general secretary is Dr. M. Bjørneboe, Kommunehospitalet, Copenhagen. Those wishing to take advantage of official arrangements for hotel accommodation should communicate with the honorary general secretary not later than May 15.

\section{Institute of Industrial Administration Summer School}

THE Institute of Industrial Administration has arranged a summer school for 'management teachers', to be held at Oriel College, Oxford, during July 26August 2. The purpose of the School is to give selected persons, responsible for the teaching of management subjects (full- and part-time), an opportunity to explore the syllabuses proposed by the Ministry of Education Committee on Education for Management and to discuss the practical teaching problems arising from it. The School will be residential and will be conducted in lecture and tutorial sessions. The chairman of the School is Major L. Urwick, chairman, Ministry of Education Committee on Education for Management. Guests will include delegates from the United States to the Eighth International Congress for Scientific Management, Stock- holm, in July. The Ministry of Education will be represented, and the 'Assembly' address will be delivered by Sir David Ross, provost of Oriel College. Application for forms and programmes should be made to : Assistant Secretary (Education), Institute of Industrial Administration, Artillery House, Artillery Row, London, S.W.1.

\section{Summer School in Relaxation Methods}

A summer school in 'Relaxation Methods' will be held at the Imperial College of Science and Technology, London, during the four weeks July 8August 1. It would seem that there is no great difficulty in acquiring such knowledge of the relaxational technique as is required to solve ordinary engineering problems (frameworks, electrical networks, etc.), so it is proposed this year to concentrate on problems involving partial differential equations in two independent variables. The course will consist of more or less formal lectures, with numerous examples to be solved under supervision; lectures will be given on Tuesdays-Fridays only, but facilities for practical work will be also provided on Mondays and (if requested) on Saturday mornings. Further particulars can be obtained from Mr. D. N. de G. Allen, Imperial College, London, S.W.7.

\section{School of Cosmic Physics, Dublin}

THE inaugural meeting of the School of Cosmic Physics in the Dublin Institute for Advanced Studies was held on March 27. The following have been appointed by the President, on the advice of the Government of Eire, to be senior professors of the School: Dr. L. W. Pollak, senior meteorological officer, Department of Industry and Commerce, Eire (from April 1) ; Dr. L. Jánossy, I.C.I. fellow at the University of Manchester (from July 1, 1947) ; and Dr. H. A. Brück, assistant director, Cambridge Observatory (from October 1, 1947).

\section{University of London: Appointments}

THE following appointments in the University of London have been announced: Prof. S. W. Wooldridge, professor of geography at Birkbeck College, to the University chair of geography tenable at King's College, as from October 1 ; Dr. P. R. Crowe, senior lecturer in geography in the University of Glasgow, to the University readership in geography tenable at Queen Mary College, as from October 1; Dr. Alfred Schweitzer, lecturer in physiology in the University of Leeds, to the University readership in experimental physiology tenable at University College, as from October 1; Mr. A. W. Skempton, senior lecturer in civil engineering at the Imperial College of Science and Technology, to the University reader. ship in soil mechanies tenable at the College, as from October 1, 1946 ; Mr. J. R. Gilmour, to the University readership in morbid anatomy tenable at London Hospital Medical College, as from October 1. The title of professor of mathematics in the University has been conferred on Dr. W. G. Bickley, in respect of the post held by him at the Imperial College of Science and Technology.

\section{Colonial Service Appointments}

THE following appointments have been made in the Colonial Service: Capt. C. N. Coombes, agricultural economist, Gold Coast; W. B. Tevendale, geologist, Gold Coast; Flight-Lieut. K. V. W. Nicholls, meteorological officer, Malaya; Flight-Lieut. R. C. 